\title{
Nutritional potential of leaves and tubers of crem (Tropaeolum pentaphyllum Lam.)
}

\author{
Potencial nutricional de folhas e \\ tubérculos de crem (Tropaeolum \\ pentaphyllum Lam.)
}

\author{
Vanessa Bernardi BRAGA ${ }^{1}$ (D) 0000-0001-7837-2451 \\ Maitê de Moraes VIEIRA² (ID)0000-0003-0225-2861 \\ Ingrid Bergman Inchausti de BARROS ${ }^{1}$ (iD) 0000-0003-1040-5303
}

A B S T R A C T

\section{Objective}

To determine the centesimal composition of minerals, fatty acids and vitamin $C$ of leaves and tubers of crem, and to discuss the nutritional potential of the $T$. pentaphyllum species.

\section{Methods}

The centesimal composition of protein, lipid, fiber, ash and carbohydrate was determined by gravimetric analysis. Mineral composition was determined by optical emission spectrometry. Vitamin $C$ was determined by dinitrophenylhydrazine method. Fatty acids were determined by gas chromatography. The percentage of recommended dietary intake of leaves and tubers of crem was calculated for each nutrient.

\section{Results}

A high content of fibrous fraction $(63.07 \mathrm{~g} / 100 \mathrm{~g})$, potassium $(4.55 \mathrm{~g} / 100 \mathrm{~g})$, magnesium $(553.64 \mathrm{mg} / 100 \mathrm{~g})$ and sulfur $(480.79 \mathrm{mg} / 100 \mathrm{~g})$ was observed in the chemical composition of leaves. In tubers, a high carbohydrate

1 Universidade Federal do Rio Grande do Sul, Faculdade de Agronomia, Programa de Pós-Graduação em Fitotecnia. Porto Alegre, RS, Brasil.

2 Universidade Federal do Rio Grande do Sul, Faculdade de Agronomia, Departamento de Zootecnia. Av. Bento Gonçalves, 7712, Agronomia, 91540-000, Porto Alegre, RS, Brasil. Correspondência para/Correspondence to: MM VIEIRA. E-mail: $<$ maite.vieira@ufrgs.br>.

Article based on the thesis by VB BRAGA, entitled: "Crem (Tropaeolum pentaphyllum Lam.), Tropaeolaceae: aspectos biológicos, nutricionais e fitotécnicos”. Universidade Federal do Rio Grande do Sul; 2017.

Como citar este artigo/How to cite this article

Braga VB, Vieira MM, Barros IBI. Nutritional potential of leaves and tubers of crem (Tropaeolum pentaphyllum Lam.). Rev Nutr. 2018;31(4):423-32. http://dx.doi.org/10.1590/1678-98652018000400007 
content was observed, with $62.60 \mathrm{~g} / 100 \mathrm{~g}$ of starch and $3.43 \mathrm{~g} / 100 \mathrm{~g}$ of fiber, as well as high potassium $(0.58 \mathrm{~g} / 100 \mathrm{~g})$, sulfur $(447.14 \mathrm{~g} / 100)$, calcium $(205.54 \mathrm{~g} / 100 \mathrm{~g})$ and phosphorus $(530.07 \mathrm{~g} / 100 \mathrm{~g})$ levels. The vitamin $C$ content of tubers was $78.43 \mathrm{mg} / 100 \mathrm{~g}$ and the linoleic acid content was $0.455 \mathrm{~g} / 100 \mathrm{~g}$. The intake of $100 \mathrm{~g}$ of crem leaves may contribute with $65 \%$ of the recommended dietary intake of sulfur. The intake of $100 \mathrm{~g}$ of crem tuber may contribute with $106 \%$ of the recommended dietary intake of sulfur and $21 \%$ of the recommended dietary intake of Vitamin $C$.

\section{Conclusion}

The chemical composition of crem (Tropaeolum pentaphyllum Lam.) tubers and leaves demonstrated an important contribution of nutrients, mainly sulfur, vitamin $C$ and linoleic acid in its tubers, indicating a high nutritional potential of this species.

Keywords: Chemical analysis. Food analysis. Nutrients. Nutritive value. Tropaeolaceae.

\section{RE S U M O}

\section{Objetivo}

Este estudo teve por objetivo determinar a composição centesimal, mineral, vitamina C e ácidos graxos de folhas e tubérculos de crem, e discutir o potencial nutricional da espécie T. pentaphyllum.

\section{Métodos}

A composição centesimal em proteínas, lipídeos, fibras, cinzas e carboidratos foi determinada por análise gravimétrica. A composição mineral foi determinada por espectrometria de emissão óptica. A vitamina $C$ foi determinada pelo método dinitrofenilhidrazina. Os ácidos graxos foram determinados por cromatografia a gás. A porcentagem da ingestão dietética recomendada de folhas e tubérculos de crem foi calculada para cada nutriente.

\section{Resultados}

Na composição química das folhas verificou-se alto conteúdo de fração fibrosa (63,07g/100g), potássio (4,55g/100g), magnésio (553,64mg/100g) e enxofre $(480,79 \mathrm{mg} / 100 \mathrm{~g})$. Nos tubérculos verificou-se alto conteúdo de carboidratos, com 62,60g/100g de amido e 3,43g/100g de fibras, além de alto teor de potássio $(0,58 \mathrm{~g} / 100 \mathrm{~g})$, enxofre $(447,14 \mathrm{~g} / 100)$, cálcio $(205,54 \mathrm{~g} / 100 \mathrm{~g})$ e fósforo $(530,07 \mathrm{~g} / 100 \mathrm{~g})$. O conteúdo de vitamina C no tubérculo de crem foi de 78,43mg/100g, e o de ácido graxo linoleico foi de 0,455 g/100g. A ingestão de $100 \mathrm{~g}$ de folhas de crem poderá contribuir com 65\% da ingestão diária recomendada de enxofre. A ingestão de $100 \mathrm{~g}$ de tubérculo de crem poderá contribuir com 106\% da ingestão diária recomendada de enxofre e com $21 \%$ da ingestão diária recomendada de Vitamina C.

\section{Conclusão}

A composição química de tubérculos e folhas de crem apresentou um aporte expressivo de nutrientes, principalmente de enxofre, além de vitamina C e ácido linoleico nos tubérculos, indicando um alto potencial nutricional da espécie.

Palavras-chave: Análise química. Análise de alimentos. Nutrientes. Valor nutritivo. Tropaeolaceae.

\section{INTRODUCTION}

Tropaeolum pentaphyllum Lam. is a native food species from Southern Brazil [1] belonging to the family Tropaeolaceae [2-3] and popularly known as batata-crem or crem [4]. Crem is consumed as traditional food by descendants of European immigrants [1]. Crem leaves can be used in salads, as the tubers can be processed and canned [4]. The nutritional potential of crem has not been not fully elucidated. There have been few recent pieces of information on the mineral composition of crem [4] and the presence of phenolic compounds in crem tubers [5], being necessary the development of studies involving the chemical composition of its leaves and tubers.

In popular therapies, the consumption of canned tubers is recommended as antiscorbutic [4]. Vitamin C is an antiscorbutic micronutrient 
and mediator of the interface between the genome and environment [6]. The antioxidant activity of vitamin C [7] has already been determined in Andean tubers (T. tuberosum) [8]. The intake of vegetables has been encouraged [9] in the modern diet to ensure the reference daily intake of $90 \mathrm{mg} /$ day of vitamin C for an adult man [10] and thus prevent various diseases related to oxidative stress [7].

The fatty acid composition of crem tubers (T. pentaphyllum) has not been sufficiently investigated, but palmitic acid and oleic acid have already been identified [11]. Fatty acids have nutritional and therapeutic benefits in the body [12], such as cholesterol reduction [13] and prevention of cardiovascular diseases [1416]. Crem tubers have been used to prevent hypercholesterolemia [4] and as an antidiabetic [17]. In the cosmopolitan species (T. majus), linoleic acid has been identified [18], which helps to reduce the risk of cardiovascular disease [19] and may be related to the positive effect of crem use in cholesterol control [4].

Considering the few studies that have been conducted on crem from a chemical perspective, the objective was to determine the mineral and centesimal composition of crem leaves and to determine the mineral and centesimal composition, and the content of vitamin $C$ and fatty acids of crem tubers. Another objective of this study was to discuss the nutritional potential of $T$. pentaphyllum species considering the chemical composition of crem leaves and tubers.

\section{METHOD S}

Samples of crem leaves and tubers were collected in two cities in the state of Rio Grande do Sul: Ipê (28 $45^{\prime} 51^{\prime \prime}$ S 5115'49" W) and Passo Fundo (28 $\left.16^{\prime} 1^{\prime \prime} \mathrm{S} 52^{\circ} 25^{\prime} 34^{\prime \prime} \mathrm{O}\right)$, in the year 2014. In each city, a collection was carried out. An exsiccation of the collected crem plants was conducted in the two localities. The exsiccated plants were deposited in the Herbarium of the Department of Botany of Universidade Federal do Rio Grande do Sul (UFRGS, Federal University of Rio Grande do Sul) under voucher ICN n ${ }^{\circ}$ 179686 (Ipê) and ICN n 179685 (Passo Fundo).

The leaves and tubers collected were homogenized and constituted a sample of each, totalizing $983 \mathrm{~g}$ of tubers and $375 \mathrm{~g}$ of crem leaves, in natural matter. Later, the sample of crem tubers was divided into two subsamples: one for the analysis of mineral and centesimal composition of dried tubers (903g) and the other for the analysis of fatty acids and vitamin C of fresh tubers $(80 \mathrm{~g})$. The leaf sample and one of the tuber subsamples were subjected to forced air oven, drying at $60^{\circ} \mathrm{C}$ for $48 \mathrm{~h}$, after which $253 \mathrm{~g}$ of dried tubers and $56 \mathrm{~g}$ of dried leaves were obtained. After dried, the samples were grinded in a $1 \mathrm{~mm}$ sieve-cutting mill. All analyzes were performed in triplicate.

\section{Centesimal composition analysis}

In the dried and ground crem leaves and tubers (forced air drying at $60^{\circ} \mathrm{C}$ for 48 hours and grinding in a cutting mill), gravimetric moisture analyzes were conducted in an oven at $105^{\circ} \mathrm{C}$ (method 930.15 ), proteins by the Kjeldahl method (method 984.13), lipids by soxhlet extraction with petroleum ether (method 920.39), fibers via sequential digestion in strong acids and bases (method 978.10), ash in a furnace-type oven at $600^{\circ} \mathrm{C}$ (method 942.05), starch via enzymatic method (method 996.11) in accordance with Association of Official Agricultural Chemistry guidelines [20]. Dry matter was estimated by the equation: Dry matter=100-Moisture. Carbohydrates were estimated by the equation: Carbohydrates $=100$ (Moisture+Proteins+Ash+Lipids+Fibers). The energy was determined in a isoperibolic calorimetric pump model C2000 (IKA Werke $\mathrm{GmbH} \&$ Co. KG, Staufen, Germany). Data were expressed as $\mathrm{g} / 100 \mathrm{~g}$ in the dry matter. 


\section{Mineral composition analysis}

The analyzes of minerals in dried and ground crem leafs and tubers were performed by Inductively Coupled Plasma Optical Emission Spectrometry (ICP-OES)adaptedfor plantmaterial [21]. The wet digestion technique followed by determination by ICP-OES was used for the analysis of phosphorus, potassium, calcium, magnesium, sulfur, copper, zinc, manganese and iron. The dry digestion technique, followed by ICP-OES determination, was used for boron analysis. Data were expressed as $\mathrm{g} / 100 \mathrm{~g}$ in the dry matter.

\section{Vitamin C determination analysis}

The content of vitamin C was analyzed in fresh tubers by the dinitrophenylhydrazine method and determined by spectrophotometry at 540nm [22]. The result was expressed in $\mathrm{mg}$ of ascorbic acid per $100 \mathrm{~g}$ of dried crem tubers.

\section{Fatty acids analysis}

The technique used for the extraction of fatty acids was static maceration [23] with hexane as solvent, in $2 \mathrm{~g}$ fresh tubers. The fatty acid composition was determined by gas chromatography coupled to mass spectrometry (GC-MS). Fatty acids were transesterified by the alkaline method [23]. The GC-MS operating conditions were: programmed temperature of the column at $50^{\circ} \mathrm{C}$ for $5 \mathrm{~min}$; heating rate at $3^{\circ} \mathrm{C}$ per min up to $240^{\circ} \mathrm{C} / 5 \mathrm{~min}$; injector temperature at $260^{\circ} \mathrm{C}$; the drag gas used was helium, with a flow rate of $1.0 \mathrm{~mL}$ per minute. Fatty acids were identified by comparing their retention times and mass spectra with reference substances (FAMEMix:18919-1, Supelco, Bellefonte, Pennsylvania). The total yield of fatty acids was $0.0056 \mathrm{~g}$ in a $2 \mathrm{~g}$ sample. The total yield of fatty acids was $0.28 \%$ in natural matter. Quantification was performed by standardizing the chromatograph where the content of each fatty acid was calculated as percentage of the fatty acid $=[($ fatty acid area/ total area of the peaks)*100]. Each percentage of fatty acid was converted to grams of fatty acid per 100 grams of dried tuber in accordance with the formula: $\mathrm{g}$ of fatty acid/ $100 \mathrm{~g}$ of dried tuber $=[(\%$ of Fatty Acid*\% Total Fatty Acid in Natural Matter)/(100-Tuber moisture)].

\section{Nutritional potential assessment}

The Recommended Dietary Allowance (RDA) of energy, carbohydrates, fiber, proteins, minerals and vitamin $C$ [10] and the result of the analysis of each component in the natural matter were used to estimate the percentage in compliance to the RDA. The result of each component in the dry matter was transformed into natural matter according to the formula exemplified as the calculation for energy in the tuber: Tuber Energy in Natural matter =Tuber Energy in Dry matter *[(100-Tuber moisture)/100].

The percentage of RDA of each component was determined according to the equation, exemplified with the calculation for energy in the tuber: \%RDA $A_{\text {Energy }}=[$ (Energy of the Tuber* 100)*RDA Energy -1$]$, where the \%RDA $A_{\text {Energy }}$ is the percentage of the reference daily intake served by the consumption of $100 \mathrm{~g}$ of tuber in natura per day; Tuber Energy is the analyzed value of Energy in $\mathrm{Kcal} / 100 \mathrm{~g}$ in natural matter; $\mathrm{RDA}_{\text {Energy }}$ is the value of the reference daily intake for an adult man with $70 \mathrm{~kg}$ of body mass [10] in $\mathrm{kcal} /$ day.

\section{Statistical analysis}

The results obtained from the centesimal composition of minerals, vitamin $\mathrm{C}$ and fatty acids were expressed in means and standard deviation through descriptive statistical analysis. 
The results of the centesimal composition of mineral, vitamin $C$ and fatty acids of crem leaves and tubers were expressed in $\mathrm{g} / 100 \mathrm{~g}$ in the dry matter in order to express the proportion of each nutrient in 100 grams of dried leaves and tubers and thus, compared to other leaves and tubers, that may exhibit variable moisture levels.
The results of the centesimal composition of mineral and vitamin $C$, used to evaluate the nutritional potential of crem leaves and tubers, were expressed in $\mathrm{g} / 100 \mathrm{~g}$ of leaves and tubers in natural matter in order to express the composition of food the way it will be consumed, and thus relate to the reference daily intake of each nutrient.

Table 1. Chemical composition of crem, expressed in dry matter. Ipê and Passo Fundo (RS), Brazil, 2014.

\begin{tabular}{|c|c|c|c|c|}
\hline \multirow{2}{*}{ Component } & \multicolumn{2}{|c|}{ Leaves* } & \multicolumn{2}{|c|}{ Tubers* } \\
\hline & $\mathrm{M}$ & SD & M & SD \\
\hline Moisture (g/100g) & 86.39 & 0.01 & 74.340 & 0.20 \\
\hline Protein (g/100g) & 14.97 & 0.30 & 9.030 & 0.22 \\
\hline Lipid (g/100g) & 5.50 & 0.12 & 0.470 & 0.01 \\
\hline Fiber $(g / 100 g)$ & 16.95 & 0.10 & 3.420 & 0.13 \\
\hline Ash (g/100g) & 16.46 & 0.09 & 4.580 & 0.04 \\
\hline Carbohydrate (g/100g) & 46.12 & 0.45 & 82.510 & 0.24 \\
\hline Energy (Kcal/100g) & 401.94 & 1.38 & 398.550 & 0.77 \\
\hline Starch (g/100g) & - & - & 62.600 & 0.44 \\
\hline$K(g / 100 g)$ & 4.55 & 0.25 & 0.580 & 0.04 \\
\hline $\mathrm{Mg}(\mathrm{mg} / 100 \mathrm{~g})$ & 553.64 & 23.04 & 155.060 & 6.25 \\
\hline $\mathrm{S}(\mathrm{mg} / 100 \mathrm{~g})$ & 480.79 & 21.94 & 447.140 & 34.77 \\
\hline $\mathrm{Ca}(\mathrm{mg} / 100 \mathrm{~g})$ & 3168.91 & 220.42 & 205.540 & 0.01 \\
\hline$P(m g / 100 g)$ & 393.38 & 22.09 & 530.070 & 39.00 \\
\hline $\mathrm{Fe}(\mathrm{mg} / 100 \mathrm{~g})$ & 21.13 & 0.63 & 4.180 & 0.06 \\
\hline $\mathrm{Mn}(\mathrm{mg} / 100 \mathrm{~g})$ & 7.28 & 0.63 & 0.830 & 0.06 \\
\hline $\mathrm{Zn}(\mathrm{mg} / 100 \mathrm{~g})$ & 5.10 & 0.63 & 1.800 & 0.17 \\
\hline$B(m g / 100 g)$ & 3.10 & 0.12 & 0.180 & 0.01 \\
\hline $\mathrm{Cu}(\mathrm{mcg} / 100 \mathrm{~g})$ & 0.91 & 0.06 & 0.580 & 0.06 \\
\hline Vitamin C (mg/100g) & & & 78.430 & 3.26 \\
\hline \multicolumn{5}{|l|}{ Fatty acids } \\
\hline Pentanedecanoic, C5:0 (g/100g) & & & 0.034 & 0.03 \\
\hline Palmitic, C16:0 (g/100g) & & & 0.407 & 0.06 \\
\hline Heptadecanoic, C17:0 (g/100g) & & & 0.006 & 0.01 \\
\hline Stearic, C18:0 (g/100g) & & & 0.014 & 0.02 \\
\hline Oleic, C18:1 (g/100g) & & & 0.237 & 0.03 \\
\hline Linoleic, C18:2n-6 (g/100g) & & & 0.455 & 0.06 \\
\hline Linolenic range, C18:3n-3 (g/100g) & & & 0.027 & 0.02 \\
\hline
\end{tabular}

Note: *M: Mean; SD: Standard Deviation, $\mathrm{n}=3$.

K: Potassium; Mg: Magnesium; S: Sulfur; Ca: Calcium; P: Phosphorus; Fe: Iron; Mn: Manganese; Zn: Zinc; B: Boron; Cu: Copper. 
RE S U L T S

\section{Chemical composition analysis}

In the chemical composition of crem leaves, a high moisture content was observed, resulting in an average dry matter of $13.61 \mathrm{~g} / 100 \mathrm{~g}$ (Table 1). Carbohydrates and fibers represented a high fibrous fraction content in the leaves (63.07g/100g). The leaves showed a high content of ash in relation to the mineral content, highlighting the $\mathrm{K} ; \mathrm{Mg}$ and $\mathrm{S}$.

The chemical composition of crem tubers showed a high moisture content, with a mean dry matter weight of $25.66 \mathrm{~g} / 100 \mathrm{~g}$. In tubers, the carbohydrates were highlighted, presenting $62.60 \mathrm{~g} / 100 \mathrm{~g}$ of starch and $3.42 \mathrm{~g} / 100 \mathrm{~g}$ of fibers. The mineral composition of tubers accentuated $\mathrm{K}, \mathrm{S}, \mathrm{Ca}$ and $\mathrm{P}$. The vitamin C content for crem tubers was high. In the composition of fatty acids, linoleic acid was the major component, while palmitic, oleic and gamma-linolenic acids were also detected.

\section{Nutritional potential assessment}

Leaves constituted a source of minerals, highlighting S with $65 \%, \mathrm{Ca}$ and $\mathrm{Mn}$ with $43 \%$ of RDA each (Table 2). The crem tubers stood out in $\mathrm{S}$ and vitamin C contributing with 106\% and $21 \%$ of the RDA respectively.

\section{I S C U S S I O N}

There are few studies on the chemical composition of crem $[4,5,11]$. The present work was based on researches made on crem ( $T$. pentaphyllum) and also on species of the same genus, mashua (T. tuberosum) $[8,20,21]$ and capuchin (T. majus) $[18,23,24]$

In the unpublished centesimal composition of crem leaves, a high ash content is related to the mineral composition of the leaves, rich in $\mathrm{K}, \mathrm{Mg}$ and $\mathrm{S}$. It was verified a different mineral composition of crem leaves collected in Porto Alegre [4], where K $(3.1 \mathrm{~g} / 100 \mathrm{~g})$ and

Table 2. Chemical composition of crem, in natural matter, and percentage of the Recommended Dietary Allowance (\%RDA) for each component. Ipê and Passo Fundo (RS), Brazil, 2014

\begin{tabular}{|c|c|c|c|c|c|c|c|c|}
\hline \multirow{2}{*}{ Component } & \multirow{2}{*}{$\mathrm{RDA}^{* *}$} & \multirow{2}{*}{ Unit } & \multicolumn{3}{|c|}{ Leaves* } & \multicolumn{3}{|c|}{ Tubers* } \\
\hline & & & $M$ & SD & \%RDA & $M$ & SD & $\%$ RDA \\
\hline Energy & 3067 & kcal/day & 54.62 & 0.19 & 2 & 102.33 & 0.86 & 3 \\
\hline Carbohydrate & 130 & g/day & 6.27 & 0.06 & 5 & 21.17 & 0.11 & 16 \\
\hline Fiber & 38 & g/day & 2.30 & 0.01 & 6 & 0.88 & 0.04 & 2 \\
\hline Protein & 50 & g/day & 2.03 & 0.04 & 4 & 2.32 & 0.07 & 5 \\
\hline K & 4,7 & g/day & 0.62 & 0.03 & 13 & 0.14 & 0.01 & 3 \\
\hline $\mathrm{Mg}$ & 260 & mg/day & 75.24 & 3.13 & 29 & 36.78 & 1.48 & 14 \\
\hline S & 100 & mg/day & 65.34 & 2.98 & 65 & 106.06 & 8.25 & 106 \\
\hline $\mathrm{Ca}$ & 1000 & mg/day & 430.65 & 29.96 & 43 & 48.75 & 0.001 & 5 \\
\hline$P$ & 700 & mg/day & 53.46 & 3.00 & 8 & 125.73 & 9.25 & 18 \\
\hline $\mathrm{Fe}$ & 14 & mg/day & 2.87 & 0.09 & 21 & 0.99 & 0.01 & 7 \\
\hline $\mathrm{Mn}$ & 2,3 & mg/day & 0.99 & 0.09 & 43 & 0.20 & 0.01 & 9 \\
\hline $\mathrm{Zn}$ & 7 & mg/day & 0.69 & 0.09 & 10 & 0.43 & 0.04 & 6 \\
\hline $\mathrm{Cu}$ & 900 & mcg/day & 0.12 & 0.01 & 0 & 0.14 & 0.01 & 0 \\
\hline B & 20 & mg/day & 0.42 & 0.02 & 2 & 0.04 & 0.001 & 0 \\
\hline Vitamin C & 90 & mg/day & - & - & - & 18.60 & 0.77 & 21 \\
\hline
\end{tabular}

Note: *M: Mean; SD: Standard Deviation, $\mathrm{n}=3$

K: Potassium; Mg: Magnesium; S: Sulfur; Ca: Calcium; P: Phosphorus; Fe: Iron; Mn: Manganese; Zn: Zinc; B: Boron; Cu: Copper; * OTTEN et al. [10]. 
S (300mg/100g) levels were lower, and Mg $(800 \mathrm{mg} / 100 \mathrm{~g})$ levels were higher than in the present study.

In the chemical composition of crem tubers, carbohydrates with high starch content and low fiber content stood out. However, a lower amount of carbohydrates $(3.44 \mathrm{~g} / 100 \mathrm{~g}$ ) and higher fiber content $(16.79 \mathrm{~g} / 100 \mathrm{~g})$ were previously observed [5]. In the centesimal composition of mashua tubers (T. tuberosum) there is a lower content of carbohydrates (74.60g/100g) [8] and starch (41.35g/100g) [24] and higher fiber content $(8.2 / 100 \mathrm{~g})$ [8], differing from crem tubers. In the mineral composition of crem tubers cultivated in Porto Alegre [4], the authors determined a content of $\mathrm{K}$ about 3 times higher than in the present study $(1.5 \mathrm{~g} / 100 \mathrm{~g})$ and, in the same way, Ca was two times higher (400mg/100g). On the other hand, these authors verified a similar level of $S(400 \mathrm{mg} / 100 \mathrm{~g})$ in this study, while the determined level of $P$ was 2 times lower than those analyzed in the present study (200mg/100g).

The differences in the chemical composition of crem leaves and tubers may be of genetic origin, as in mashua [25], or due to planting sites, with different edaphoclimatic conditions and cultivation systems.

The popular use of crem as an antiscorbutic [4] may be related to the antioxidant properties of vitamin C [7], which have already been detected in Andean tubers [8]. However, there was as yet no record of vitamin $C$ content in crem. Despite the lack of data on vitamin C content in the subject species, it was possible to verify that vitamin $C$ content of crem tubers was high when compared to Colocasia esculenta tubers, popularly known as taro $(0.20 \mathrm{mg} / 100 \mathrm{~g}$ of fresh taro) [26]. However, the vitamin C content of capuchin ( $T$. majus) both in fresh flowers (256mg/100g) [27] and in lyophilized leaves and flowers (10mg/g) [28] was higher than in this study. Consequently, the vitamin C content of crem tubers determined here was unprecedented and could be used for future comparisons.
In the composition of fatty acids, the major component was linoleic acid, followed by palmitic, oleic and gamma-linolenic acids. Palmitic and oleic acids have already been identified in crem tubers [11] and linoleic acid has been identified in capuchin leaves and flowers [18]. These fatty acids have health benefits [12-14], from cholesterol reduction [13] to prevention [16], protection [15] and risk reduction [19] of cardiovascular diseases. Cholesterol reduction is also associated to the intake of myristic and palmitic fatty acids [13].

The consumption of monounsaturated fatty acid, such as oleic acid, has a beneficial effect on lipid profile markers, besides helping to prevent cardiovascular diseases [16]. Polyunsaturated fatty acids, such as gammalinolenic acid, also act as protectors in the prevention of cardiovascular diseases [15]. The higher consumption of linoleic acid is strongly associated with a decreased risk of cardiovascular diseases [19]. Therefore, the fatty acid composition of crem tubers may be related to the therapeutic effects reported by the popular use of crem as hypocholesterolemic [4].

The nutritional potential of crem leaves was as a source of minerals, mainly $\mathrm{S}, \mathrm{Ca}, \mathrm{Mn}$, all above $20 \%$ of the RDA. Despite this high contribution, there is no information on the bioavailability of these minerals, which may be related to oxalates and phytates [29], which means that these minerals cannot be used by the organism. Therefore, the high concentration of sulfur (65\% of the RDA) may restrict the consumption of crem leaves, as this element adds more bitterness to the taste of the leaves [30].

Crem tubers were significantly higher in relation to the RDAs of sulfur and vitamin C, representing a high nutritional potential. The most prominent mineral element in crem, both in leaves and tubers, was sulfur. Sulfur may be related to glucosinolates [26] present in species of the genus Tropaeolum [18,31].

Benzyl isothiocyanate (0.65\%) [11] has already been determined in crem plants. 
Glucotropaleolin was determined in capuchin leaves [32], one of the main glucosinolates found in the genus Tropaeolum [18]. Glucosinolates and sulfur have antifungal properties [11] that may be related to the therapeutic effects of crem [32].

Vitamin C contribution of crem tubers can reach $21 \%$ of the RDA for adult men. The popular recommendation of canned crem as antiscorbutic [4] seems consistent, since the intake of crem can contribute with a greater quantity of vitamin $C$ in the body, besides other nutrients. Vitamin $\mathrm{C}$ also acts as a biological antioxidant [7], which justifies the incentive to consume vegetables in the modern diet [9], which includes crem tubers and leaves. In this context, the consumption of crem tubers may contribute to the prevention of scurvy [4] by supplying part of the reference daily intake of vitamin $C$ and in the prevention of diseases related to oxidative stress [7].

The analysis of the chemical composition of crem leaves and tubers evidenced, in an unprecedented way, that both constitute high quality material for food use. In the leaf composition, a high fiber content was highlighted, and in crem tubers a high carbohydrate content stood out. Regarding mineral composition, the most present element was $S$, with the possibility of contributing with more than $60 \%$ of the reference daily intake established for an adult. In relation to tubers, the contents of vitamin $C$ and linoleic acid in the composition of fatty acids were highlighted. Therefore, crem showed a high nutritional potential in its chemical composition.

\section{CONCLUSION}

Crem leaves are composed mainly of fibers. Crem tubers are rich in carbohydrates, especially starch, and contain significant amounts of vitamin $C$ and linoleic acid.

Both leaves and tubers of crem showed an important contribution of nutrients, mainly sulfur. Tubers serve more than $20 \%$ of the RDA in vitamin $\mathrm{C}$, indicating the high nutritional potential of this species.

\section{CONTRIBUTORS}

VB BRAGA and IBI BARROS conceived and designed the experiments and contributed providing reagents and material; VB BRAGA and MM VIEIRA performed the experiment and analyzed the data; $V B$ BRAGA, MM VIEIRA and IBI BARROS interpreted the data and wrote the article.

\section{REFERENCES}

1. Chaves A, Zanin EM. Etnobotânica em comunidades rurais de origem italiana e polonesa do município de Erechim, RS. Perspectivas. 2012;36(133):95-113.

2. Rix M. Tropaeolum Pentaphyllum Tropaeolaceae. Curtis's Bot Mag. 2010;27(3):296-300. http:// dx.doi.org/10.1111/j.1467-8748.2010.01706.x

3. Guerra E, Streher NS, Lüdtke R. Plantas trepadeiras do Horto Botânico Irmão Teodoro Luis, sul do Rio Grande do Sul, Brasil. Rev Bras Biociênc. 2015;13(4):201-9.

4. Kinupp VF, Lorenzi $H$. Plantas Alimentícias Não-Convencionais (PANC) no Brasil: guia de identificação, aspectos nutricionais e receitas ilustradas. Nova Odessa: Plantarum; 2014.

5. Simões GD. Crem (Tropaeolum pentaphyllum Lam.): caracterização química, antioxidante e sua aplicação como condimento em uma pasta vegetal [dissertação]. Santa Maria: Universidade Federal de Santa Maria; 2015.

6. Young Jl, Züchner S, Wang G. Regulation of the epigenome by vitamin C. Annu Rev Nutr. 2015;35:545-64. http://dx.doi.org/10.1146/annurevnutr-071714-034228

7. Michels AJ, Hagen TM, Frei B. Human genetic variation influences vitamin $C$ homeostasis by altering vitamin $\mathrm{C}$ transport and antioxidant enzyme function. Annu Rev Nutr. 2013;33:45-70. http://dx.doi.org/10.1146/annurev-nutr-07181 2-161246

8. King S, Gershoff SN. Nutritional evaluation of three underexploited Andean tubers: Oxalis tuberosa (Oxalidaceae), Ullucus tuberosus (Basellaceae), and Tropaeolum tuberosum (Tropaeolaceae). Econ Bot. 1987;41(4):503-11. http://dx.doi.org/10.100 7/BF02908144 
9. Martin C, Zhang Y, Tonelli C, Petroni K. Plants, diet, and health. Annu Rev Plant Biol. 2013;64:19-46. http://dx.doi.org/10.1146/annurev-arplant-050 312-120142

10. Otten JJ, Hellwig JP, Meyers LD. Dietary reference intake: The essential guide to nutrient requirements. Washington (DC): The National Academies Press; 2006.

11. Cruz MCS, Denardi LB, Mossmann NJ, Piana M, Alves SH, Campos MMA. Antimicrobial activity and chromatographic analysis of extracts from Tropaeolum pentaphyllum Lam. tubers. Molecules. 2016;21(566):1-11. http://dx.doi.org/10.3390/ molecules21050566

12. Siri-Tarino PW, Chiu S, Bergeron N, Krauss RM. Saturated fats versus polyunsaturated fats versus carbohydrates for cardiovascular disease prevention and treatment. Annu Rev Nutr. 2015;35:517-43. http://dx.doi.org/10.1146/ annurev-nutr-071714-034449

13. Miller JC, Smith C, Willians SM, Mann J, Brown RC, Parnell WR, et al. Trends in serum total cholesterol and dietary fat intakes in New Zealand between 1989 and 2009. Aust N Z J Public Health. 2016;40(3):263-9. http://dx.doi. org/10.1111/1753-6405.12504

14. Zock PL, Blom WAM, Nettleton JA, Hornstra G. Progressing insights into the role of dietary fats in the prevention of cardiovascular disease. Curr Cardiol Rep. 2016;18(111):1-13. http://dx.doi. org/10.1007/s11886-016-0793-y

15. Fengqiong $L$, Zhongxia $L$, Xiaofei $L$, Jing $M$. Dietary $n-3$ polyunsaturated fatty acid intakes modify the effect of genetic variation in fatty acid desaturase 1 on coronary artery disease. Plos One. 2015;10(4):1-10. http://dx.doi.org/10.1371/ journal.pone.0121255

16. Lopes LL, Peluzio MCG, Hermsdorff HHM. Ingestão de ácidos graxos monoinsaturados e metabolismo lipídico. J Vasc Bras. 2016;15(1):52-60. http:// dx.doi.org/10.1590/1677-5449.008515

17. Trojan-Rodrigues M, Alves TLS, Soares GLC, Ritter MR. Plants used as antidiabetics in popular medicine in Rio Grande do Sul, southern Brazil. J Ethnopharmacol. 2012;139(1):155-63. http:// dx.doi.org/10.1016/j.jep.2011.10.034

18. Brondani JC, Cuelho CHF, Morangoni LD, Lima R, Guex CG, Bonilha IF, et al. Traditional usages, botany, phytochemistry, biological activity and toxicology of Tropaeolum majus L.: A review. Bol Latinoam Caribe Plant Med Aromaticas. 2016;15(4):264-73.

19. Farvid MS, Ding M, Pan A, Sun Q, Chiuve SE, Steffen $L M$, et al. Dietary linoleic acid and risk of coronary heart disease: A systematic review and metaanalysis of prospective cohort studies. Epidemiol Prev Circ. 2014;130(18):1568-78. http://dx.doi. org/10.1161/circulationaha.114.010236

20. Association of Official Agricultural Chemistry. Official methods of analysis. 16th ed. Arlington: AOAC International; 1995.

21. Tedesco MJ, Gianello C. Metodologia de análises de solo, plantas, adubos orgânicos e resíduos. In: Bissani CA, Gianello C, Camargo FAO, Tedesco MJ. Fertilidade dos solos e manejo da adubação de culturas. Porto Alegre: Genesis; 2004. p.61-6.

22. Terada M, Watanabe $Y$, Kunitomo M, Hayashi E. Differential rapid analysis of ascorbic acid and ascorbic acid 2-sulfate by dinitrophenylhydrazine method. Anal Biochem. 1978;84(2):604-8. http:// dx.doi.org/10.1016/0003-2697(78)90083-0

23. Andrade JM, Marin R, Apel MA, Raseira MCB, Henriques AT. Comparison of the fatty acid profiles of edible native fruit seeds from southern Brazil. Inter J Food Prop. 2012;15(4):815-22. http:// dx.doi.org/10.1080/10942912.2010.503355

24. Valcárcel-Yamani B, Rondán-Sanabria G, Finardi-Filho F. The physical, chemical and functional characterization of starches from Andean tubers: Oca (Oxalis tuberosa Molina), olluco (Ullucus tuberosus Caldas) and mashua (Tropaeolum tuberosum Ruiz \& Pavón). Braz J Pharm Sci. 2013;49(3):453-64. http://dx.doi.org/10.1590/S19 84-82502013000300007

25. Quispe C, Mansilla R, Chacón A, Blas R. Análisis de la variabilidad morfológica del "añu" Tropaeolum Tuberosum Ruiz \& Pavón procedente de nueve distritos de la región Cusco. Ecol Apl. 2015;14(2):211-22.

26. Castro DS, Oliveira TKB, Lemos DM, Rocha APT, Almeida RD. Efeito da temperatura sobre a composição físico-química e compostos biativos de farinha de taro obtida em leite de jorro. Braz J Food Technol. 2017;20:1-5. http://dx.doi. org/10.1590/1981-6723.6016

27. Fernandes L, Casal S, Pereira JA, Saraiva JA, Ramalhosa E. Uma perspectiva nutricional sobre flores comestíveis. Acta Port Nutr. 2016;6:32-7. http://dx.doi.org/10.21011/apn.2016.0606

28. Bazylko A, Parzonko A, Jez W, Osinska E, Kiss AK. Inhibition of ROS production, photoprotection, and total phenolic, flavonoids and ascorbic acid content of fresh herb juice and extracts from the leaves and flowers of Tropaeolum majus. Ind Crops Prod. 2014;55:19-24. http://dx.doi.org/10.1016/j. indcrop.2014.01.056

29. Amalraj A, Pius A. Bioavailability of calcium and its absorption inhibitors in raw and cooked green leafy vegetables commonly consumed in India: An 
in vitro study. Food Chem. 2015;170:430-6. http:// dx.doi.org/10.1016/j.foodchem.2014.08.031

30. Wieczorek MN, Walczak M, Skrzypczak-Zielinska $\mathrm{M}$, Jelén $\mathrm{HH}$. Bitter taste of Brassica vegetables: The role of genetic factors, receptors, isothiocyanates, glucosinolates and flavor context. J Crit Rev Food Sci Nutr. 2017;(in press). http://dx.doi.org/10.108 0/10408398.2017.1353478

31. Guzman-Perez V, Bumke-Vogt C, Schreiner $M$, Mewis I, Borchet A, Pfeiffer AFH. Benzylglucosinolate derived isothiocyanate from Tropaeolum majus reduces gluconeogenic gene and protein expression in human cells. Plos One.
2016;13:1-27. http://dx.doi.org/10.1371/journal. pone.0162397

32. Platz $S$, Kühn $C$, Schiess $S$, Schreiner $M$, Kemper M, Pivovarova O, et al. Bioavailability and metabolism of benzyl glucosinolate in humans consuming Indian cress (Tropaeolum majus L.). Mol Nutr Food Res. 2016;60(3):652-60. http:// dx.doi.org/10.1002/mnfr.201500633

Received: February 5, 2018

Final version: July 6, 2018

Approved: August 13, 2018 